\title{
Antibiotic susceptibility of Neisseria gonorrhoeae isolated in the Western Pacific in 1971
}

\author{
LAURENCE P. WATKO* AND WILFRED J. BROWNLOW† \\ From the Navy Environmental and Preventive Medicine Unit No. 6*, Pearl Harbour, Hawaii, and the \\ Navy Environmental and Preventive Medicine Unit No. 2, $\uparrow$ Norfolk, Virginia
}

Personnel developing acute urethritis aboard an aircraft carrier were examined bacteriologically for causative agents before treatment. Their infections were contracted during in-port periods, primarily in Olongopo City, Republic of the Philippine Islands. This paper reports the in vitro susceptibility of strains of Neisseria gonorrhoeae isolated from 256 of these patients.

\section{Material and methods}

The population from which the patients were obtained consisted of men deployed on an attack aircraft carrier operating in the Gulf of Tonkin during the latter half of 1971. Patients reporting to sickbay with a complaint of dysuria or a urethral discharge, were examined for acute urethritis by microscopic examination of Gram-stained preparations of the discharge, culture of urethral scrapings, and culture of urinary sediment. Individuals found to have $N$. gonorrhoeae by stained preparations and confirmed by cultural procedures were diagnosed as having acute gonococcal urethritis; the therapeutic regimens used for these patients have been described previously (Brownlow, Watko, Aucoin, and Iglecia, 1974).

When the patient reported to sickbay urethral exudate was obtained and he was then requested to provide a urine specimen from the initial portion of his urinary stream. A $15 \mathrm{ml}$. aliquot of urine was centrifuged at 1,500 r.p.m. for $10 \mathrm{~min}$. The supernatant urine was decanted off, and portions of the sediment cultured for $N$. gonorrhoeae on media described below. The urethral exudate was collected by inserting a $4 \mathrm{~mm}$. platinum wire loop 1.0 to $1.5 \mathrm{~cm}$. into the urethra and gently withdrawing it while simultaneously applying pressure to the surface of the urethra. The exudate was applied to GC medium enriched with haemoglobin to which was added 1.0 per cent. Isovitalex enrichment and 1.0 per cent. VCN inhibitor (Martin, Billings, Hackney, and Thayer, 1967). After incubation

Received for publication May 21, 1974

The opinions and assertions contained herein are those of the authors and are not to be construed as official or reflecting the views of the Navy Department or the Naval Service at large.

Reprint requests should be submitted to Officer in Charge, Navy Environmental and Preventive Medicine Unit No. 2, Norfolk, Virginia 23511 for 18 to $24 \mathrm{hrs}$ at $36^{\circ} \mathrm{C} . \pm 1^{\circ} \mathrm{C}$. in an atmosphere of approximately 5 per cent. $\mathrm{CO}_{2}$ (candle extinction jar), single colonies of isolates which proved to be Gramnegative diplococci, and oxidase positive, were subcultured on VCN-free medium overnight under the same conditions. These strains of $N$. gonorrhoeae were stored aboard ship at $-70^{\circ} \mathrm{C}$. in trypticase soy broth containing 30 per cent. agammaglobulin horse serum; subsequently these cultures were used in carbohydrate reactions to confirm the species, and in the antibiotic susceptibility tests. At approximately 3 to 4 -week intervals the clinical specimens were transported under dry ice refrigeration to the laboratory in Hawaii.

In vitro antibiotic susceptibility testing of the $N$. gonorrhoeae isolates was done according to a standard plate-dilution method described by Thayer and Martin (1966). The concentration of antibiotic required to produce total inhibition of growth constituted the minimum inhibitory concentration (MIC) for the isolates tested.

\section{Results}

The in vitro susceptibilities of isolates of $N$. gonorrhoeae to five antibiotics are enumerated in Table I. The disparity in the total number of isolates for each antibiotic may be attributed primarily to the logistics of transporting fresh isolates from aboard a warship in the Gulf of Tonkin to the laboratory in Hawaii, and to the loss of viable cultures during storage awaiting susceptibility testing. Isolates were tested for susceptibility to penicillin in a range from 0.05 to $2 \mu \mathrm{g} . / \mathrm{ml}$. Only 9.3 per cent. of this group were inhibited by $0.05 \mu \mathrm{g} . / \mathrm{ml}$. while 46.1 per cent. required $0.5 \mu \mathrm{g} . / \mathrm{ml}$. or greater concentrations to be inhibited. 1.2 per cent. of the cultures required $2 \mu \mathrm{g} . / \mathrm{ml}$. The median MIC for penicillin of these isolates is $0.23 \mu \mathrm{g} . / \mathrm{ml}$.

The susceptibility of isolates to tetracycline was tested in concentrations ranging from $0 \cdot 1$ to $6 \mu \mathrm{g} . / \mathrm{ml}$. This group of isolates was inhibited over the range of 0.5 to $5 \mu \mathrm{g} . / \mathrm{ml}$. with a median MIC of $1.2 \mu \mathrm{g} . / \mathrm{ml}$. Of these cultures $40 \cdot 7$ per cent. were inhibited by $1 \mu \mathrm{g} . / \mathrm{ml}$. or less, while 16.5 per cent. required more than $2 \mu \mathrm{g} . / \mathrm{ml}$. The median MIC for tetracycline of these isolates is $1.2 \mu \mathrm{g} . / \mathrm{ml}$. 
TABLE I The in vitro susceptibility of isolates of Neisseria gonorrhoeae to antibiotics

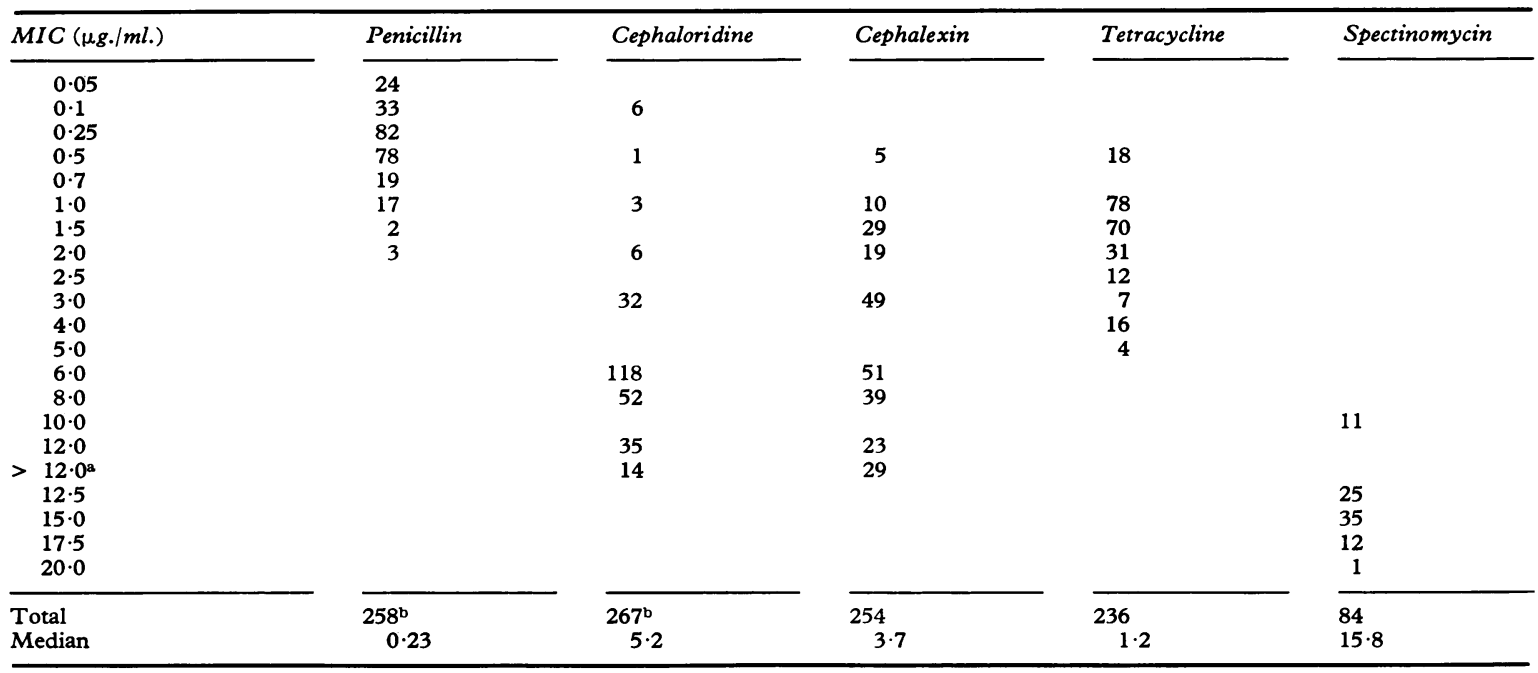

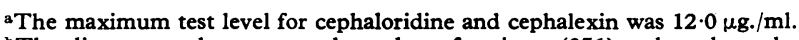

bThe discrepancy between total number of patients (256) and total number of isolates was due to occasionally obtaining more than one culture from the same patient, e.g. on consecutive days before treatment or when treatment had failed

The susceptibility of isolates to cephaloridine and cephalexin exhibited similar patterns although the median MIC of cephaloridine $(5 \cdot 2 \mu \mathrm{g} . / \mathrm{ml}$.) was greater than that of cephalexin $(3 \cdot 7 \mu \mathrm{g} . / \mathrm{ml}$.). A concentration of $1 \mu \mathrm{g} . / \mathrm{ml}$. or less of cephaloridine inhibited growth of 3.7 per cent. of the isolates while the same concentrations were effective against 5.9 per cent. of cultures tested against cephalexin. Concentrations greater than $6 \mu \mathrm{g} . / \mathrm{ml}$. were required to inhibit growth of 37.8 per cent. of cultures tested against cephaloridine, and 35.8 per cent. of those tested against cephalexin.

Of all the antibiotics, spectinomycin required the highest concentration for inhibition of growth of $N$. gonorrhoeae. Cultures were inhibited in the relatively narrow range of 10 to $20 \mu \mathrm{g}$. $/ \mathrm{ml}$. with a median of $12.9 \mu \mathrm{g} . / \mathrm{ml}$.

Product-moment coefficient correlations of isolates of $N$. gonorrhoeae for paired antibiotics are calculated in Table II. Moderate correlations are demonstrated for susceptibility to penicillin, cephaloridine, and tetracycline while lower correlations usually occurred with the antibiotics paired with spectinomycin.

The data in Table II are biased by the exclusion of paired observations in which one of the isolates was not inhibited by one of the antibiotics at the maximum concentration tested. This effect is most pronounced with the combination of cephalexin and tetracycline. Recalculation of the correlation coefficient with the open-ended data by assigning arbitary maximum MIC values did not significantly alter the values in Table II except for the combination of cephalexin and tetracycline. In this instance
TABLE II Product-moment correlation coefficients $(r)$ of the in vitro susceptibility of Neisseria gonorrhoeae to antibiotics

\begin{tabular}{llll}
\hline Antibiotics & $\begin{array}{l}\text { Number of } \\
\text { isolates }\end{array}$ & $r$ \\
\cline { 1 - 1 } $\begin{array}{l}\text { Penicillin and cephaloridine } \\
\text { Penicillin and cephalexin }\end{array}$ & 246 & \\
Penicillin and tetracycline & 223 & 0.68 \\
Penicillin and spectinomycin & 235 & 0.24 \\
Spectinomycin and cephaloridine & 84 & 0.62 \\
Spectinomycin and cephalexin & 79 & 0.32 \\
Spectinomycin and tetracycline & 83 & $0.22^{\mathrm{a}}$ \\
Tetracycline and cephaloridine & 220 & 0.48 \\
Tetracycline and cephalexin & 198 & 0.30 \\
Cephaloridine and cephalexin & 221 & 0.57 \\
\hline P & $0.01,0 x c e p t$ that & 0.01 & 0.34 \\
\hline
\end{tabular}

$\mathrm{P}<0.01$, except that ${ }^{\mathrm{a}} 0.01<\mathrm{P}<0.05$, and ${ }^{\mathrm{b}} \mathrm{P}>0.05$

$r=.03$ became $r=.23$ when it was assumed that the maximum MIC for cephalexin was $15 \mu \mathrm{g} . / \mathrm{ml}$.

\section{Discussion}

It is believed generally that $N$. gonorrhoeae is becoming more resistant to penicillin. Direct comparisons of the in vitro susceptibility of the organism reported by various studies are difficult. Tabulated values of minimum inhibitory concentrations (MIC) of antibiotics, or proportions of isolates inhibited over different ranges of antibiotic concentrations containing MIC concentrations tested at various levels, complicate the interpretation of data. Universal acceptance of standard procedures discussed by Reyn, Bentzon, and Ericsson (1963) would resolve these difficulties, but few laboratories seem to be prepared to undertake these analytical procedures in lieu of simple MIC determinations. Since 
MIC values are the most frequent method of reporting the susceptibility of $N$. gonorrhoeae to antibiotics in vitro, we belive the median to be a useful, single statistic for the comparison of ranges of MIC values with different concentrations of antibiotics tested within these ranges.

The median has the advantages of simplicity of calculation, of utilization with open-ended data encountered with MIC values, and of not being affected by a few extreme values as would be the mean of a range of values. However, the assumption must be made that the isolates are uniformly distributed with respect to inhibition by the antibiotics between the concentrations titrated; furthermore, the median cannot be used in tests of significance which utilize the mean and deviations about the mean.

In order to compare our data with earlier reports in the literature, the median MIC values of data from other studies have been calculated and are shown in Table III. As is generally acknowledged, a trend with time is noted toward decreased susceptibility to penicillin in vitro, and an effect of geographical location is evident. The median MIC values from southeast Asia tend to be considerably higher than those reported from other major geographical areas of the world.

The MIC values for $N$. gonorrhoeae to penicillin and cephaloridine observed in this study were similar to those reported by Keys, Halverson, and Clarke (1969). The median MIC for penicillin in 1971 was $0.23 \mu \mathrm{g} . / \mathrm{ml}$., and in 1969 it was 0.22 $\mu \mathrm{g} . / \mathrm{ml}$. The median MIC for cephaloridine was $5.2 \mu \mathrm{g} . / \mathrm{ml}$. in 1971 , and in 1969 it was $6.1 \mu \mathrm{g} . / \mathrm{ml}$.

Thus 46 per cent. of isolates in 1971 and 44 per cent. of isolates in 1969 required $0.5 \mu \mathrm{g} . / \mathrm{ml}$. or greater concentrations of penicillin for inhibition of growth, and 82 and 83 per cent. in 1971 and 1969 respectively required $5 \mu \mathrm{g} . / \mathrm{ml}$. or greater of cephaloridine for inhibition of growth.

In contrast to Maness and Sparling (1973), who found no correlation between sensitivities to spectinomycin and other drugs for 29 strains of $N$. gonorrhoeae we found a significant, positive correlation coefficient between the susceptibility in vitro of spectinomycin, penicillin, cephaloridine, and tetracycline for our isolates. Duncan (1972) also reported a positive correlation coefficient between spectinomycin and penicillin sensitivities in isolates from 82 patients. While he reported a range from 5 to $15 \mu \mathrm{g} . \mathrm{ml}$. for MIC values of spectinomycin (median $8 \cdot 6$ ), the range of our isolates to spectinomycin was 10 to 20 $\mu \mathrm{g} . / \mathrm{ml}$. (median 12.9). It is tempting to speculate that these minor differences are real, and that they are related to the geographical origin of the two groups of cultures, since the cultures of this study were from the Philippine Islands while those of Duncan were from Texas, U.S.A. Indeed, calculation of the mean values for each group of MIC values and submitting them to analysis by a t-test of significance reveals a highly significant statistical difference between the two means $(\mathbf{P}<\cdot 01)$. However, this speculation infers that this drug is involved in multiple resistance, since the decreased susceptibility to penicillin of $N$. gonorrhoeae originating in the Western Pacific region is demonstrated in Table III and has been discussed by Willcox (1970). However, the data of Sparling (1972) and Maness and Sparling (1973) suggest that resistance to spectinomycin is not under the same genetic control as penicillin sensitivity in multiple drug resistance patterns.

The MIC values of isolates from patients who fail to respond to treatment are of interest; however,

TABLE III Median values for the minimum inhibitory concentrations of penicillin for Neisseria gonorrhoeae

\begin{tabular}{|c|c|c|c|c|c|}
\hline \multicolumn{2}{|l|}{ Source } & \multirow{2}{*}{ Country } & \multirow{2}{*}{$\begin{array}{l}\text { Year of } \\
\text { study }\end{array}$} & \multirow{2}{*}{$\begin{array}{l}\text { Number of } \\
\text { strains }\end{array}$} & \multirow{2}{*}{$\begin{array}{l}\text { Median } \\
(\mu g . / m l .)\end{array}$} \\
\hline Authors & Date & & & & \\
\hline $\begin{array}{l}\text { Romansky and Robin } \\
\text { Del Love and Finland } \\
\text { Curtis and Wilkinson } \\
\text { Cradock-Watson, Shooter, and Nicol } \\
\text { Thayer, Field, Perry, Martin, and Garson } \\
\text { Amies } \\
\text { Gjessing and Odegaard } \\
\text { Snell, Norris, and Strong } \\
\text { Amies } \\
\text { Nicol, Ridley, and Symonds } \\
\text { Smith and Levy } \\
\text { Ho and Chang } \\
\text { Moses, Desai, Bhosle, and Trasi } \\
\text { Keys, Halverson, and Clarke } \\
\text { Silverstein } \\
\text { Panikabutra and Suvanmalik } \\
\text { Present study } \\
\text { Duncan }\end{array}$ & $\begin{array}{l}1947 \\
1955 \\
1958 \\
1958 \\
1961 \\
1967 \\
1964 \\
1963 \\
1967 \\
1968 \\
1967 \\
1967 \\
1971 \\
1969 \\
1973 \\
1973 \\
1975 \\
1972\end{array}$ & $\begin{array}{l}\text { USA } \\
\text { USA } \\
\text { England } \\
\text { England } \\
\text { USA } \\
\text { Canada } \\
\text { Norway } \\
\text { Canada } \\
\text { Canada } \\
\text { England } \\
\text { Australia } \\
\text { Taipei } \\
\text { India } \\
\text { Philippines } \\
\text { Taipei } \\
\text { Thailand } \\
\text { Philippines } \\
\text { USA }\end{array}$ & $\begin{array}{l}1947 \\
1954 \\
1957 \\
1957 \\
1959 \\
1959 \\
1959-1962 \\
1963 \\
1966 \\
1966 \\
1967 \\
1967 \\
1968-1969 \\
1968-1969 \\
1970 \\
1967-1970 \\
1971 \\
1972\end{array}$ & $\begin{array}{r}53 \\
106 \\
302 \\
200 \\
368 \\
320 \\
1000 \\
200 \\
979 \\
91 \\
104 \\
59 \\
216 \\
242 \\
130 \\
96 \\
258 \\
81\end{array}$ & $\begin{array}{l}0.012 \\
0.003 \\
0.006 \\
0.009 \\
0.021 \\
0.005 \\
0.016 \\
0.018 \\
0.053 \\
0.022 \\
0.027 \\
0.059 \\
0.129 \\
0.223 \\
0.256 \\
0.133 \\
0.232 \\
0.045\end{array}$ \\
\hline
\end{tabular}

MIC values originally reported in units $/ \mathrm{ml}$. have been converted to $\mu \mathrm{g} . / \mathrm{ml}$. 
TABLE IV Minimum inhibitory concentrations of antibiotics for isolates of Neisseria gonorrhoeae recovered from patients successfully and unsuccessfully treated for acute gonococcal urethritis

\begin{tabular}{|c|c|c|c|c|c|c|}
\hline \multirow{3}{*}{$\begin{array}{l}\text { Original } \\
\text { drug regimen }\end{array}$} & \multicolumn{6}{|c|}{ Outcome of original treatment regimen } \\
\hline & \multicolumn{2}{|l|}{ Success } & \multicolumn{4}{|l|}{ Failure } \\
\hline & $\begin{array}{l}\text { Pre-treatment } \\
\text { median } M I C \\
(\mu \mathrm{g} . / \mathrm{ml} .)\end{array}$ & $\begin{array}{l}\text { Number of } \\
\text { isolates }\end{array}$ & $\begin{array}{l}\text { Pre-treatment } \\
\text { median MIC } \\
(\mu \mathrm{g} . / \mathrm{ml} .)\end{array}$ & $\begin{array}{l}\text { Number of } \\
\text { isolates }\end{array}$ & $\begin{array}{l}\text { Post-treatment } \\
\text { median MIC } \\
(\mu \mathrm{g} . / \mathrm{ml} .)\end{array}$ & $\begin{array}{l}\text { Number of } \\
\text { isolates }\end{array}$ \\
\hline $\begin{array}{l}\text { Penicillin } \\
\text { Cephaloridine } \\
\text { Cephalexin }\end{array}$ & $\begin{array}{l}0 \cdot 2 \\
5 \cdot 2 \\
3 \cdot 9\end{array}$ & $\begin{array}{l}255 \\
266 \\
237\end{array}$ & $\begin{array}{l}0 \cdot 2 \\
6 \cdot 0 \\
7 \cdot 5\end{array}$ & $\begin{array}{r}3 \\
1 \\
11\end{array}$ & $2 \cdot 3$ & $\begin{array}{l}0 \\
0 \\
6\end{array}$ \\
\hline
\end{tabular}

very few of these isolates were obtained for laboratory evaluation during this study. The paucity of isolates is attributed to the high success rate observed with the drug regimens used combined with the loss of viability of 50 per cent of the isolates before completion of the laboratory studies. Limited data is presented in Table IV, where the similarity of MIC values of isolates from successfully and unsuccessfully treated patients with acute gonococcal urethritis is demonstrated. These observations support the impression that one should use caution in selecting antibiotic therapy solely on the basis of in vitro sensitivity patterns. The comments of Lankford (1945) 30 years ago that the interaction of drug, pathogen, and host factors determine the outcome of treatment are pertinent today.

\section{Summary}

Isolates of Neisseria gonorrhoeae from 256 patients contracting acute gonococcal urethritis, primarily in the Republic of the Philippine Islands, in 1971, were tested for the minimum inhibitory concentrations of five antibiotics. The median is advocated as a measurement for comparison of ranges of MIC values; the median MIC of penicillin for 258 isolates was $0.23 \mu \mathrm{g} . / \mathrm{ml}$. A positive correlation coefficient was observed for the susceptibility of isolates to penicillin, spectinomycin, cephaloridine, and tetracycline.

The authors wish to express their appreciation to HMC John M. Webber, HM2 Richard W. Hannold, and HM2 R. C. Washburn for technical assistance. Analytical standards for cephaloridine (Loridine) and cephalexin (Keflex) were provided through the courtesy of Eli Lilly Laboratories, and spectinomycin (Trobicin) was provided through the courtesy of the Upjohn Company.

\section{References}

Amirs, C. R. (1967) Canad. med. Ass. F., 96, 33

Brownlow, W. J., WatKo, L. P., AucoIN, E. J., and IGLECIA, R. (1974) Brit. f. vener. Dis., 50, 113

Cradock-Watson, J. E., Shooter, R. A., and Nicol, C. S. (1958) Brit. med. F., 1, 1091

CuRTIS, F. R., and WILkINSON, A. E. (1958) Brit. F. vener. Dis., 34, 70

Del LoVe, B. JR., and Finland, M. (1955) Arch. intern. Med., 95, 66

Duncan, W. C. (1972) 'Epidemic Venereal Disease' (Proc. 2nd Int. Vener. Dis. Symposium, St. Louis), p. 68
Gjessing, H. C., and ÖdegaArd, K. (1964) Acta derm.venereol. (Stockh.), 44, 132

Ho, T. J., and Chang, S. S. (1967) Far East med. F., 3, 320

Keys, T. F., Halverson, C. W., and Clarke, E. J., Jr. (1969) f. Amer. med. Ass., 210, 857

LANKFord, C. E. (1945) Amer. F. Syph., 29, 56

MANESS, M. J., and Sparling, P. F. (1973) f. infect. Dis., 128, 321

Martin, J. E., Billings, T. E., Hackney, J. F., and Thayer, J. D. (1967) Publ. Hlth Rep. (Wash), 82, 361

Moses, J. M., Desai, M. S., Bhosle, C. B., and Trasi, M. S. (1971) Brit. F. vener. Dis., 47, 273

Nicol, C. S., RIdley, M., and Symonds, M. A. E. (1968) Ibid., 44, 315

Panikabutra, K., and Suvanmalik, S. (1973) Ibid., 49, 209

Reyn, A., Bentzon, M. W., and Ericsson, H. (1963) Acta path. microbiol. scand., 57, 235

Romansky, M. J., and RoBIN, E. V. D. (1947) Amer. F. Syph., 31, 271

Silverstein, D. M. (1973) Milit. Med., 138, 16

Smith, D. D., and Levey, J. M. (1967) Med. F. Aust., 1, 849

Snell, E., Norris, D. A., and Strong, J. (1963) Canad. med. Ass. F., 89, 601

Sparling, P. F. (1972) 'Epidemic Venereal Disease' (Proc. 2nd Int. Vener. Dis. Symposium, St. Louis), p. 58

Thayer, J. D., Field, F. W., Perry, M. I., Martin, J. E. JR., and GaRsoN, W. (1961) Bull. Wld Hlth Org., 24, 327

- and Martin, J. E. JR. (1966) 'Procedure for Determining Penicillin Susceptibility of $N$. gonorrhoeae'. U.S. Public Health Service, NCDC, Atlanta

Willcox, R. R. (1970) Brit. F. vener. Dis., 46, 217

La sensibilité aux antibiotiques de Neisseria gonorrhoeae dans le Pacifique oriental en 1971

\section{SOMMAIRE}

La concentration inhibitrice minima fut recherchée vis-à-vis de cinq antibiotiques sur des isolements de Neisseria gonorrhoeae chez 256 malades atteints d'urétrite gonococciqe aigüe, principalement dans la République des Îles Philippines en 1971. On préconise la médiane comme moyen statistique de comparaison des niveaux des valeurs de la CIM, et cette médiane de la CIM de pénicilline pour 258 isolements fut de $0,23 \mu \mathrm{g} / \mathrm{ml}$. Un coefficient positif de corrélation fut constaté dans la sensibilité des isolements vis-à-vis de pénicilline, spectinomycine, céphaloridine et tétracycline. 